\title{
Özel Eğitimde Serbest Zaman Becerileri ile İlgili Yapılan Çalışmaların Genel Eğilimleri
}

\author{
Arş. Gör. Nesime Kübra TERZİOĞLU* \\ Abant İzzet Baysal Üniversitesi, Eğitim Bilimleri Enstitüsü, Gölköy / Bolu / Türkiye, \\ kubrakeskin@ibu.edu.tr, ORCID: 0000-0002-2041-5049 \\ Dr. Öğr. Üyesi Müzeyyen ELDENIZ-ÇETİN \\ Abant İzzet Baysal Üniversitesi, Eğitim Fakültesi, Gölköy / Bolu / Türkiye, \\ meldeniz1@ hotmail.com, ORCID: 0000-0001-9231-7344
}

\section{$\ddot{\mathbf{O z}}$}

Araştırmanın amacı özel eğitimde serbest zaman becerileri ile ilgili 2000-2017 yılları arasında yapılmış olan çalışmaların içerik ve yöntemsel eğilimlerini belirlemektir. Araştırma konusu ve amacı nedeniyle bu araştırmada doküman incelemesi metodu kullanılmıştır. Araştırma sürecinde ulaşılan dokümanlar internet aracılığı ile elektronik bir formatta elde edilmiştir. Mevcut araştırmada dokümanlara ulaşmak amacı ile Google Akademik arama motoru, Yükseköğretim Kurulu'nun (YÖK) Ulusal Tez Merkezi internet sitesi ve Abant İzzet Baysal Üniversitesi Kütüphanesi abone veri tabanları kullanılmıştır. Bu veri tabanlarına "boş zaman”, "serbest zaman”, "rekreasyon" gibi anahtar kelimeler kullanılarak dokümanlara ulaşabilmek için taramalar yapılmıştır. İnceleme sonucunda tam metnine ulaşılmayan, kullanım izni olmayan ve 2000 yılından önce yayınlanan çalışmalar mevcut araştırmaya dâhil edilmemiştir. Ay-

* Sorumlu Yazar. Tel: +90 3742541000

(C) 2018 Kalem Eğitim ve Sağlık Hizmetleri Vakfı. Bütün Hakları Saklıdır. 
rıca hem tezi hem de tezden üretilen makalesi olan araştırmalardan yalnızca biri değerlendirmeye alınmıştır. Çalışmalar betimsel analiz ile çözümlenmiştir. Araştırma kapsamında toplanan veriler her bir araştırma sorusuna karşılık gelecek şekilde verilerin frekansları hesaplanmıştır. Elde edilen veriler tablolar ve grafikler ile sunularak yorumlanmıştır.

Anahtar Kelimeler: Serbest zaman; Serbest zaman aktiviteleri; Rekreasyon; Özel eğitim; Döküman incelemesi.

\title{
General Trends of Studies on Leisure Time Skills in Special Education
}

\begin{abstract}
Aim of this study is to identify the contents and methodological tendencies of studies related to leisure time activity skills, conducted between 2000-2017. Because of its context and purpose, document review method is used in this study. The documents have been accessed in electronic form through internet. In order to access the documents, Google Scholar search engine, website of Higher Education Council (YOK) National Thesis Center and Abant İzzet Baysal University Library database have been used. By entering key words; such as "free time", "leisure time" and "recreation", documents have been scanned and reviewed. During the review process, studies written before 2000 and are prohibited to use or whose full text is not provided have not been included in the study. Also, only one of the researches, which is in thesis form and an article based on that thesis, has been included. At the end of this limitation, a total of 42 studies have been included in the research. The studies have been analyzed through descriptive analysis method. Data gathered during the study was calculated the frequency of the data correspondingly to each research question. The obtained data are presented and interpreted in tables and graphs.
\end{abstract}

Keywords: Leisure time; Leisure time activities; Recreation; Special education; Document review.

\section{Extended Summary}

\section{Purpose}

Aim of this study is to identify the contents and methodological tendencies of studies related to leisure time activity skills, conducted between 2000- 
2017. For this purpose, the following questions are sought for answers: (1) In which journals have the studies on leisure time activity skills in special education been published? (2) What is the division of studies on leisure time activity skills in special education, according to years? (3) What are the common research methods used in the studies on leisure time activity skills in special education? (4) What is the division of sampling levels and their sizes of studies on leisure time activity skills in special education? (5) What are the common data analysis methods used in the studies on leisure time activity skills in special education?

\section{Method}

Because of its context and purpose, document review method is used in this study. The documents have been accessed in electronic form through internet. To access the documents, Google Scholar search engine, website of Higher Education Council (YOK) National Thesis Center and Abant İzzet Baysal University Library database have been used. By entering key words; such as "free time", "leisure time" and "recreation", documents have been scanned and reviewed. As a result, a total of 84 studies conducted in Turkey and abroad have been accessed. Acquired studies have been reviewed by the researchers. During the review process, studies written before 2000 and are prohibited to use or whose full text is not provided have not been included in the study. Also, only one of the researches, which is in thesis form and an article based on that thesis, has been included. At the end of this limitation, a total of 42 studies have been included in the research. The studies have been analyzed through descriptive analysis method. Collected data has been analyzed by means of descriptive statistical method (frequency).

\section{Result}

In this research, studies on leisure time activity skills in special education, which are conducted in Turkey and abroad, between 2000-2017, have been analyzed in terms of type of research, place and year of publication, research methods, level and number of samples, and data analysis methods. The study revealed that between 2000-2017 most of the articles were published in Developmental Medicine \& Child Neurology; 4 of the articles were published in journals originated in Turkey and 32 of them were published in journals abroad; and that most of the studies on leisure time skills were conducted in 2009. Another finding is that, in these studies quantitative and qualitative methods are more prominent; statistical analysis methods are widely used in 
quantitative researches; statistical, content and descriptive analysis methods are used in qualitative researches; and that in single subject researches, the graphical analysis methods are used.

\section{Discussion and Conclusion}

Briefly it can be suggested that, in terms of the number of analyzed studies and the research questions, this is a comprehensive research for the identification of the tendencies of studies on leisure time activity skills in special education conducted in Turkey and abroad. It can also be asserted that this study will be helpful for clarifying the strong and deficient sides of the previous researches, and that it can be used as a determinative study to shed light upon the future studies. Nonetheless, the results are limited within the studies conducted between 2000-2017 and whose full texts have been accessed.

\section{Giriş}

Serbest zaman bireyin temel gereksinimlerini karşıladıktan ve okul, iş, ev sorumlulukları gibi çalışma dışı zorunluluklarını yerine getirdikten sonra özgürce seçebileceği etkinliklere katılabileceği zaman olarak ifade edilebilir. Serbest zaman etkinlikleri ise bireylerin içinde bulunmayı seçtiği herhangi bir etkinlik olarak tanımlanabilir (Yalon-Chamovitz, Mano, Jarus ve Weinblatt, 2006). Serbest zaman etkinlikleri, kitap okumadan arkadaş toplantılarına kadar uzanan, kişisel doyumdan sosyal doyuma kadar yarar sağlayan geniş bir yelpaze içinde ele alınabilir (Braun, Yeargin-Allsopp ve Lollar, 2006).

Serbest zaman etkinlikleri; (1) grup, (2) sosyal ve (3) bireysel etkinlikler olmak üzere üçe ayrılmaktadır. Grup etkinlikleri, çocuğun ev ortamının dışında gerçekleşen ve sosyal etkileşimini kolaylaştıran etkinliklerdir. Sosyal çevre etkinlikleri, sosyal ve günlük hayatta gerçekleşen etkinliklerdir. Bireysel etkinlikler ise çocuğun yaşadığı çevrede oluşan ve başkalarıyla etkileşim kurmayı gerektirmeyen etkinliklerdir (Ittenbach, Bruininks, Thurlow ve McGrew, 1993).

Serbest zamanlarda yapılan bireysel, grup ya da sosyal etkinlikler bireyler için önemli olup farklı alanlarda fayda sağlamaktadır. Serbest zaman etkinliklerini seçmek ve o etkinliklere katılmak bireylerin akranları ile sosyalleşmesine, kişisel ilgilerini keşfetmesine ve yaşam doyumu sağlamalarına katk1 sağlamaktadır (Caldwell ve Gilbert, 1990; Kinney ve Coyle, 1992; McManus, Corcoran ve Perry, 2008; Simpkins, Ripke, Huston ve Eccles, 
2005; Yalon-Chamovitz, Mano, Jarus ve Weinblatt, 2006). Serbest zaman etkinliklerine katılmak normal gelişim gösteren bireyler için olduğu kadar özel gereksinimli öğrenciler için de o denli önem taşımaktadır. Serbest zaman etkinliklerine katılım özel gereksinimli bireylerin arkadaşlıklar kurmasına, yeteneklerinin geliştirilmesine, zihnî ve fizikî sağlı̆̆ının güçlenmesine, yaşamdaki amaçlarını ve anlamlarını belirlemelerine katkı sağlamaktadır (Brown, Brown ve Bayer, 1994; Brown ve Gordon, 1987; Fidler ve Fidler, 1978; Lyons, 1993, Parmenter, Cummins, Shaddock, ve Stancliffe, 1994; Schleien, Green ve Heyne, 1993).

Özel gereksinimli bireyler ve serbest zaman araştırmaları son yirmi yılda giderek artarak akademik araştırma alanlarının odak noktası hâline gelmiştir. Serbest zaman becerileri ile ilgili akademik alanda yapılan çalışmalar artmasına rağmen, özel gereksinimli bireylere yönelik bu konuda yapılan uygulamalar artmamıştır (Aitchison, 2000). Bu araştırma ile son yıllarda özel gereksinimli bireylere yönelik yapılan serbest zaman çalışmalarının genel eğilimlerini belirlemenin hem akademik alanda gelmiş olduğumuz noktayı görebilmemize hem de araştırmanın sonuçları itibariyle özel gereksinimli bireylerin serbest zamanlarını değerlendirebilecekleri uygulama alanlarının geliştirebilmesine katkı sağlayabileceği düşünülmektedir.

Alanyazın tarandığında özel eğitimde serbest zaman becerileri araştırmalarını belli ölçütlere göre değerlendiren bir araştırmaya rastlanmamıştır. Bu bağlamda özel eğitimde yapılan serbest zaman becerileri çalışmalarının incelenmesi, içerik ve yöntem eğilimlerinin belirlenmesi yapılacak araştırmalar için rehber olacağı düşünülmektedir. Bu araştırmanın amacı özel eğitimde serbest zaman becerileri ile ilgili 2000-2017 yılları arasında yapılmış olan çalışmaların içerik ve yöntem eğilimlerini belirlemektir. Bu amaç doğrultusunda aşağıdaki sorulara yanıt aranmıştır:

1. Özel eğitimde serbest zaman becerileri ile ilgili yapılmış olan çalışmalar hangi dergilerde yayınlanmıştır?

2. Özel eğitimde serbest zaman becerileri ile ilgili yapılmış olan çalışmaların yıllara göre dağılımı nasıldır?

3. Özel eğitimde serbest zaman becerileri ile ilgili yapılmış olan çalışmalarda hangi araştırma yöntemleri yaygın olarak kullanılmıştır?

4. Özel eğitimde serbest zaman becerileri ile ilgili yapılmış olan çalışmaların örneklem düzeyleri ve büyüklüklerinin dağılımı nasıldır? 
272 Arş. Gör. Nesime Kübra TERZİOĞLU / Dr. Öğr. Üyesi Müzeyyen ELDENİZ-ÇETİN

5. Özel eğitimde serbest zaman becerileri ile ilgili yapılmış olan çalışmalarda yaygın olarak kullanılan veri analiz yöntemleri nelerdir?

\section{Yöntem}

\section{Araştırma Modeli}

Araştırmada konusu ve amacı nedeniyle doküman incelemesi metodu kullanılmıştır. Doküman incelemesi; araştırılması hedeflenen olgu veya olgular hakkında bilgi içeren yazılı materyallerin incelenmesi sürecini kapsamaktadır (Yıldırım ve Şimşek, 2016). Şekil 1'de doküman inceleme süreci yer almaktadır. Mevcut araştırma Şekil 1'deki merhaleler dikkate alınarak gerçekleştirilmiştir.

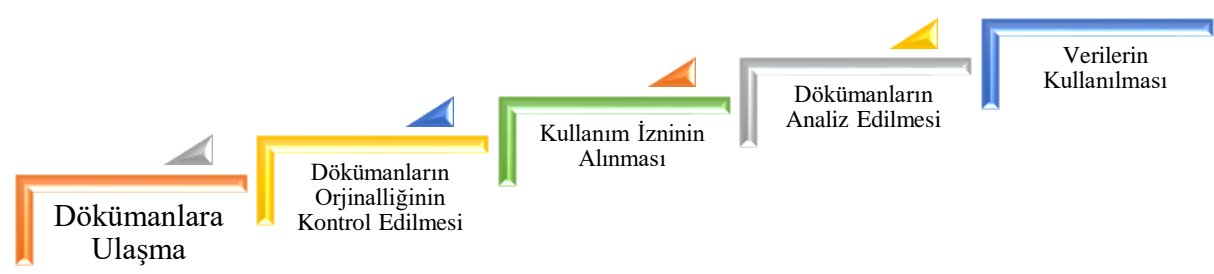

Şekil 1. Doküman incelemesi süreci (Baş ve Akturan, 2013).

\section{Veri Toplama Süreci}

Araştırma sürecinde ulaşılan dokümanlar internet aracıllğı ile elektronik bir formatta elde edilmiştir. Elektronik veri kaynaklarının başka kaynaklara erişimi mümkün kılması gibi esnek yapıya sahip olması, geniş bir coğrafi bölgeden örnekleme yapabilme imkânının olması (Baş ve Akturan, 2013) mevcut araştırmada elektronik formatın seçilmesinin nedenleri arasındadır. Mevcut araştırmada dokümanlara ulaşmak amacı ile Google Akademik arama motoru, Yükseköğretim Kurulu'nun (YÖK) Ulusal Tez Merkezi internet sitesi ve Abant İzzet Baysal Üniversitesi Kütüphanesi abone veri tabanları kullanılmıştır. Bu veri tabanlarına "boş zaman”, "serbest zaman”, "rekreasyon” gibi anahtar kelimeler kullanılarak dokümanlara ulaşabilmek için taramalar yapılmıştır. Tarama sonucunda ulaşılan makale ve tezlerin referanslarına gidilerek taramalar genişletilmiştir. Türkiye ve Yurt Dışı adresli 84 tane çalışmaya ulaŞılmıştır. Elde edilen çalışmalar araştırmacılar tarafından incelenmiştir. İnceleme sonucunda tam metnine ulaşılmayan, kullanım izni olmayan ve 2000 y1lından önce yayınlanmış olan çalışmalar mevcut araştırmaya dâhil edilmemiş- 
tir. Ayrıca hem tezi hem de tezden üretilen makalesi olan araştırmalardan yalnızca biri değerlendirmeye alınmıştır. Bu sınırlandırma süreci sonunda belirlenen 42 çalışma araştırma kapsamına alınmıştır. Bu çalışmalara ilişkin bilgiler Tablo 1'de görülmektedir.

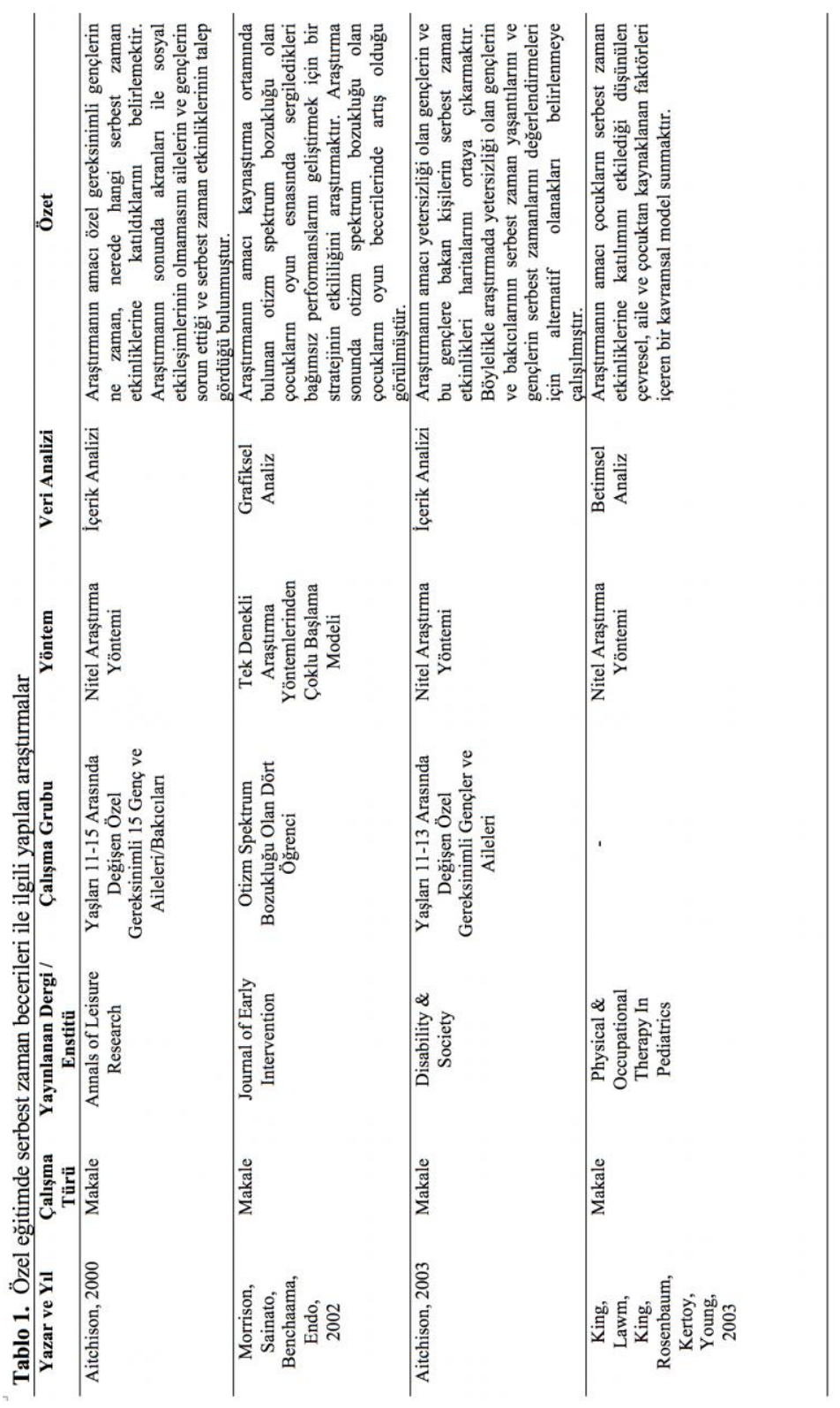




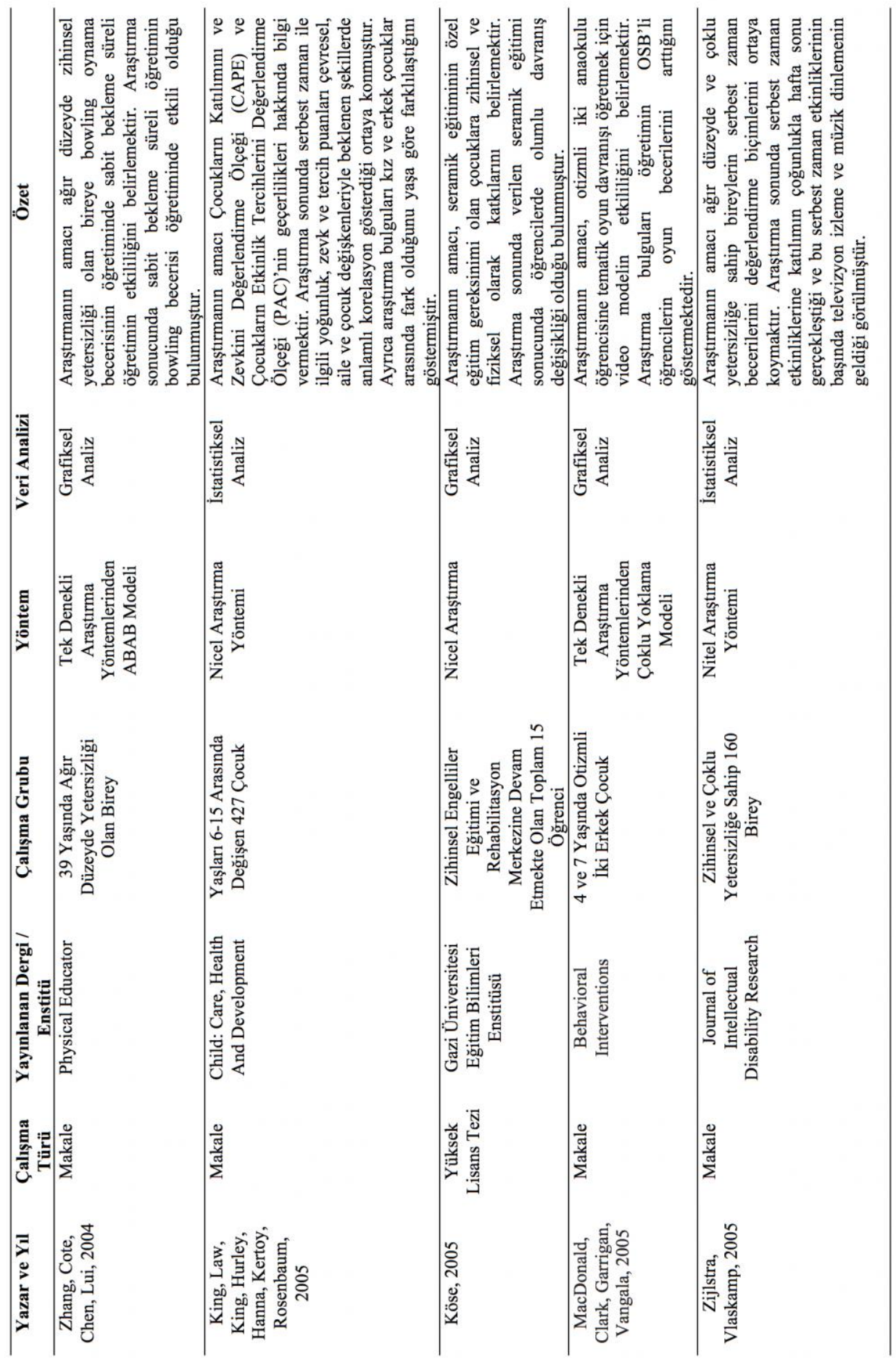




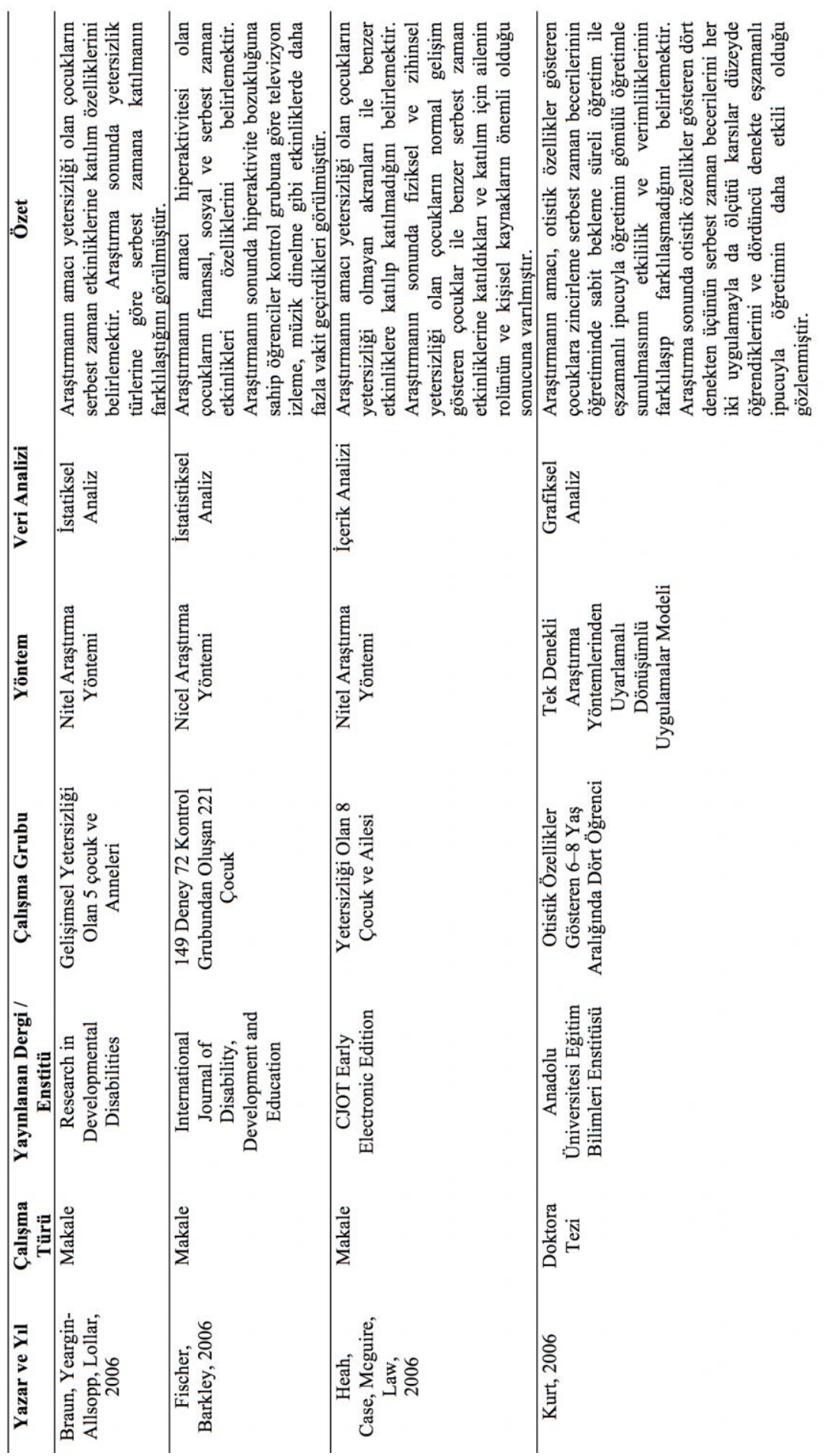




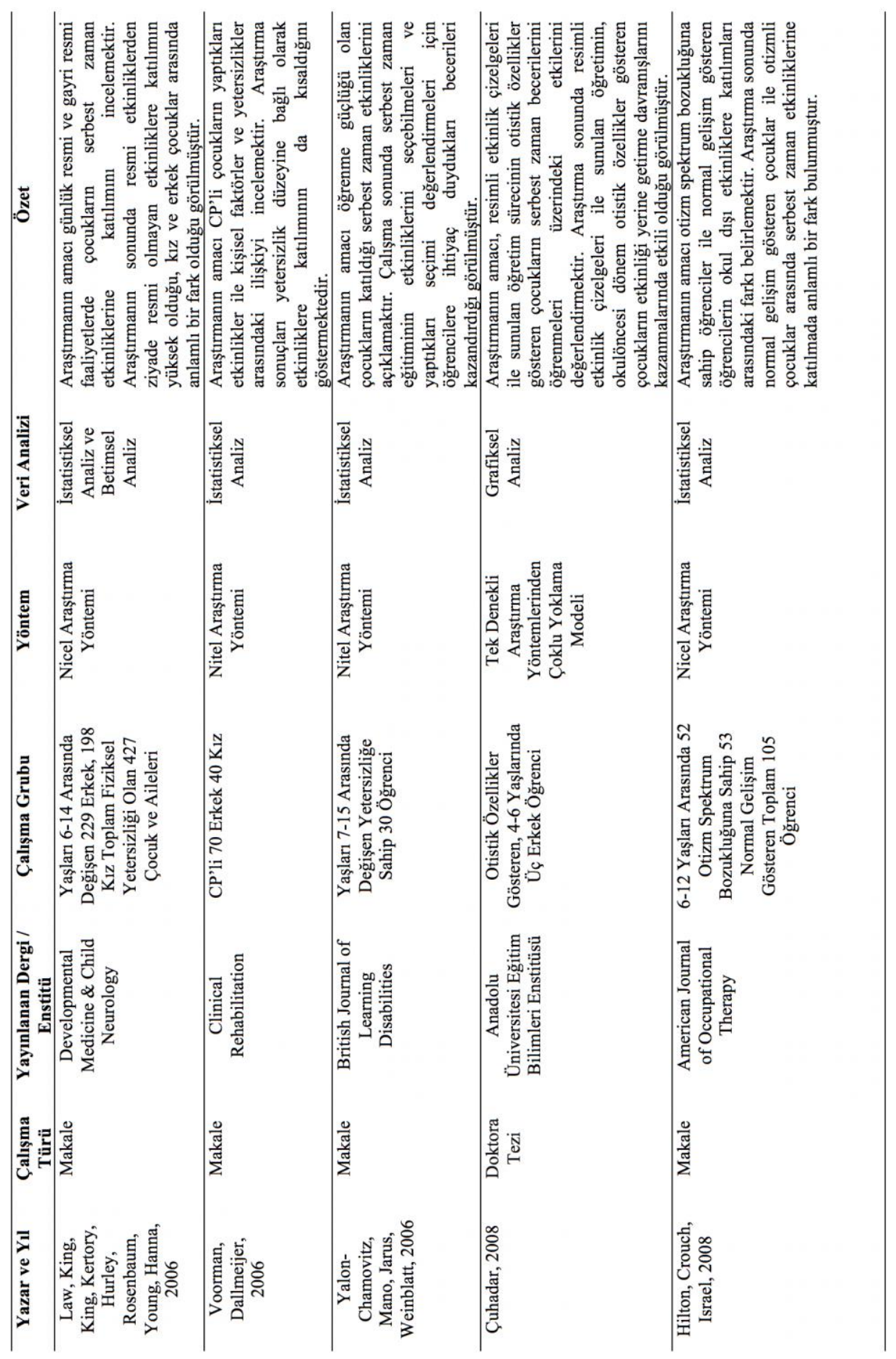




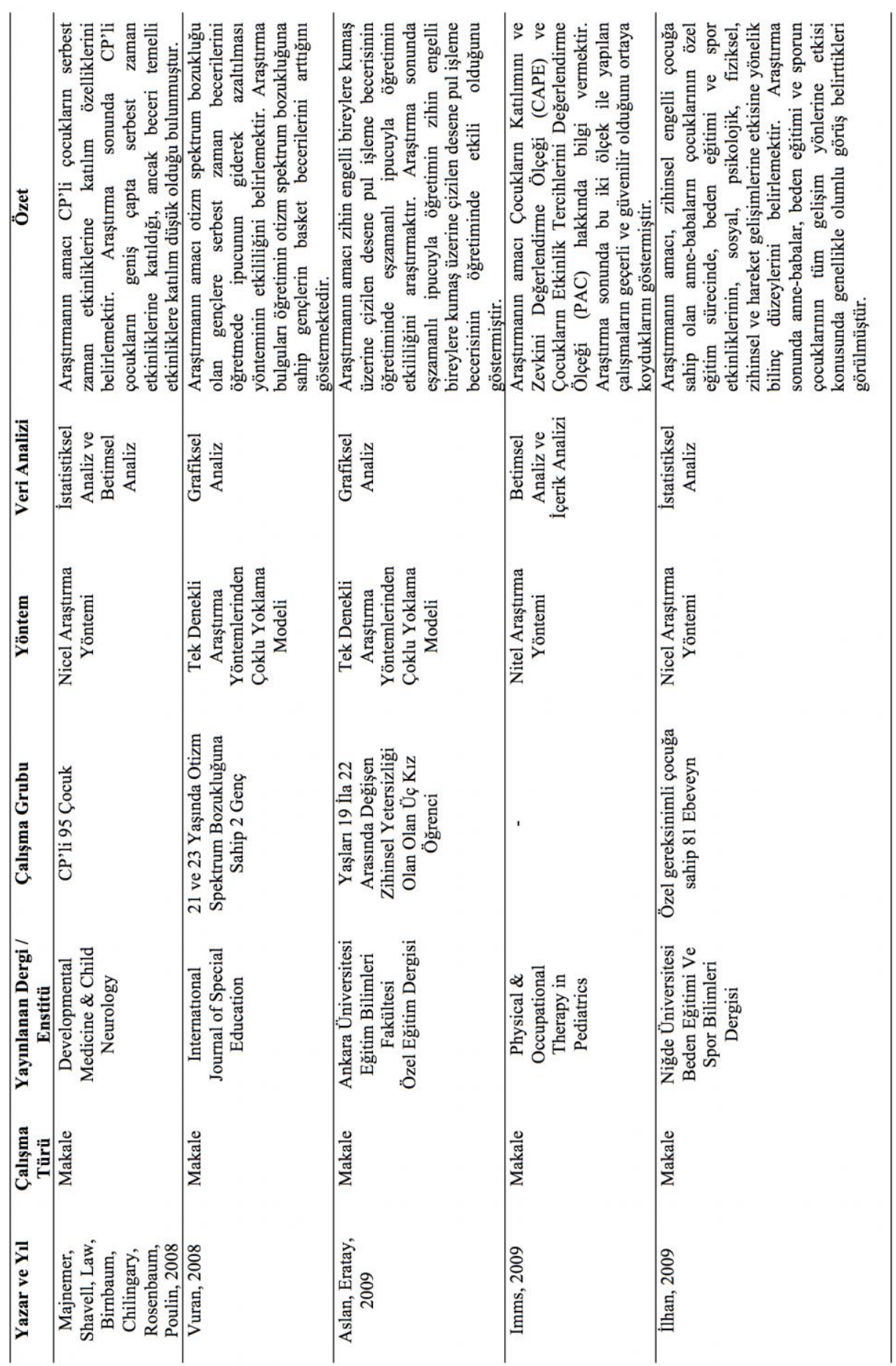




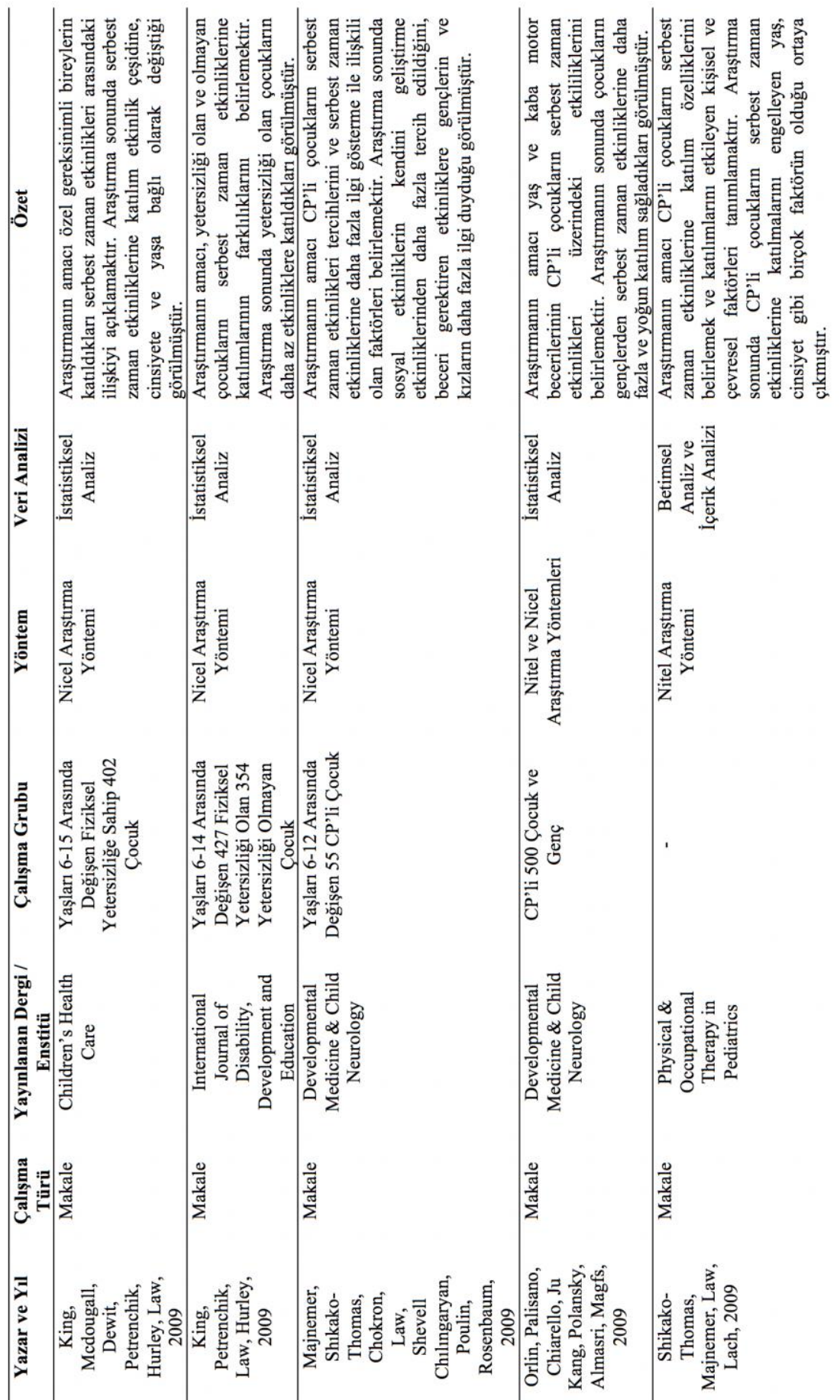




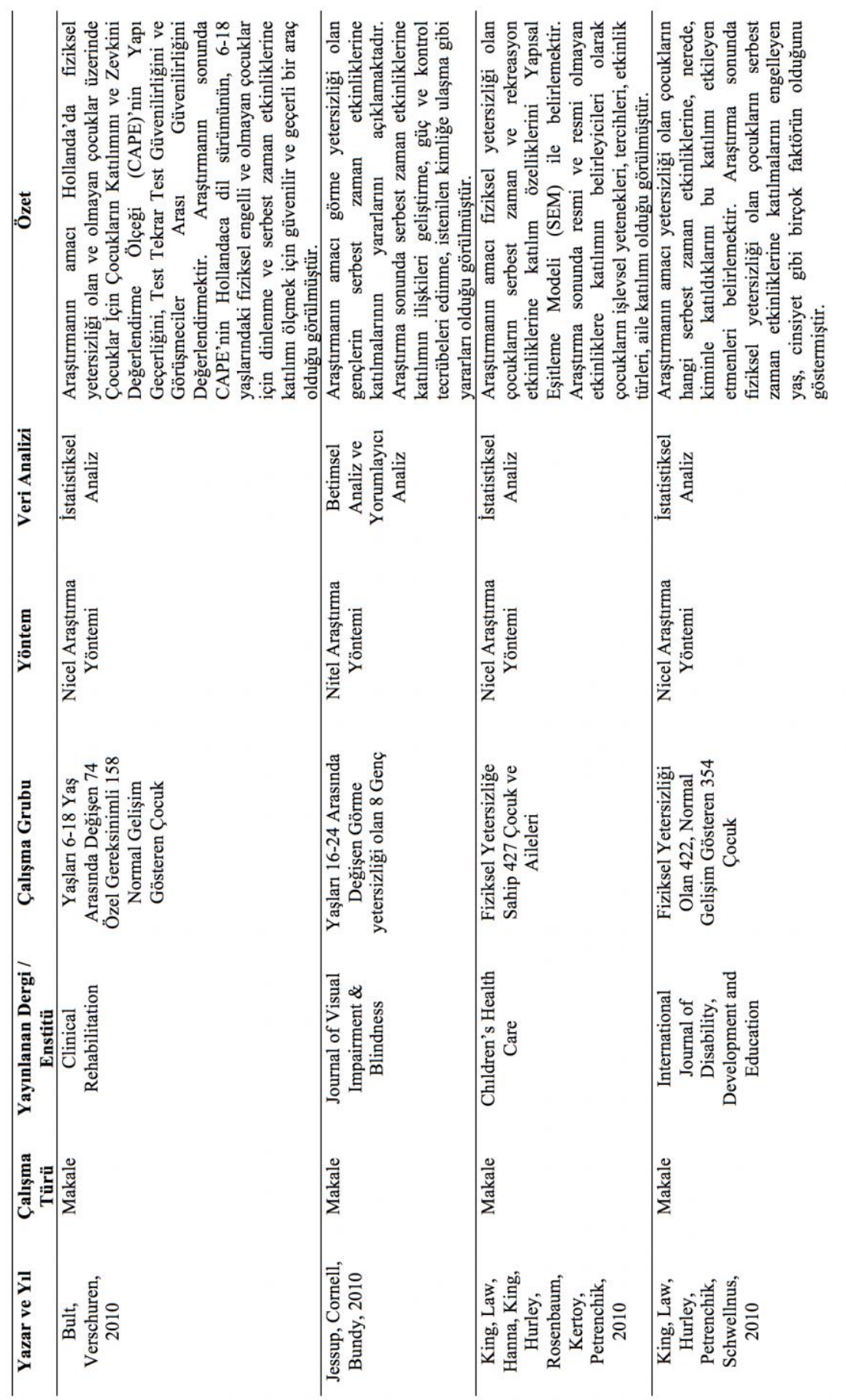




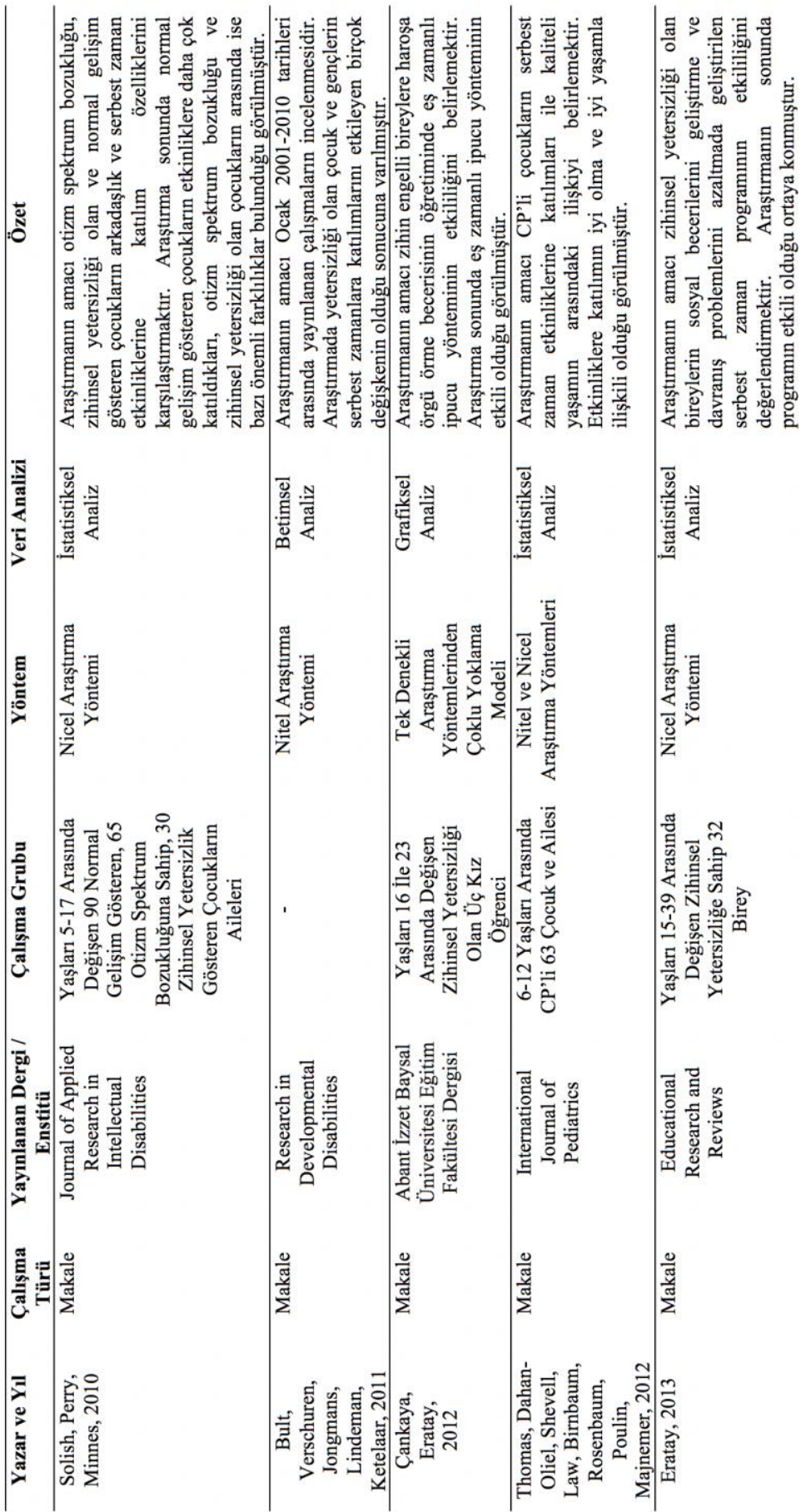




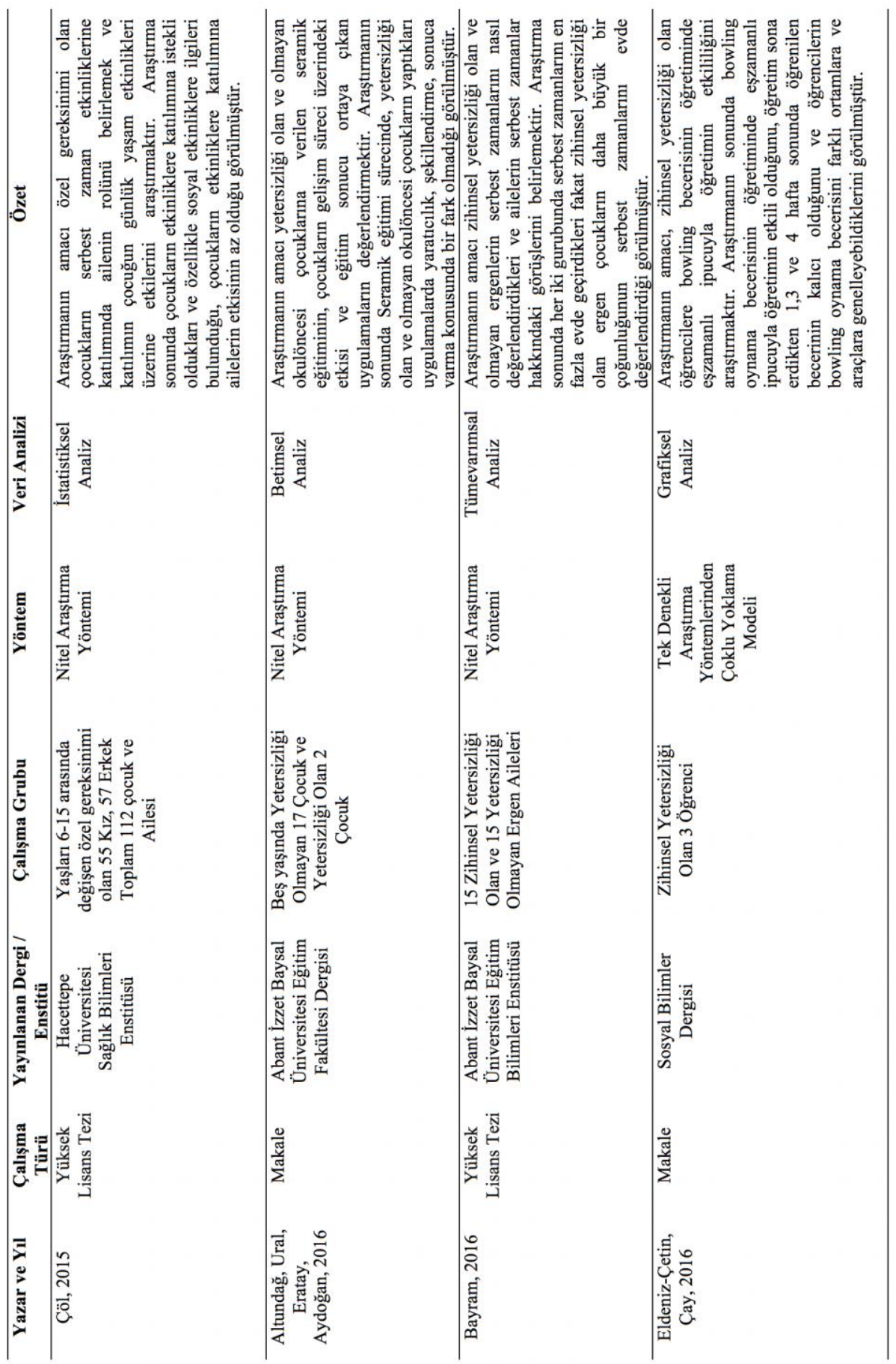




\begin{tabular}{|c|c|c|c|c|c|c|}
\hline Çay, 2017 & $\begin{array}{c}\text { Yüksek } \\
\text { Lisans Tezi }\end{array}$ & $\begin{array}{l}\text { Abant İzet Baysal } \\
\text { Unniversitesi Eğitim } \\
\text { Bilimleri Enstitüsü }\end{array}$ & $\begin{array}{c}\text { Zihinsel Yetersizliği } \\
\text { Olan } 18 \text { Yaşlarında } 3 \\
\text { Birey }\end{array}$ & $\begin{array}{c}\text { Tek Denekli } \\
\text { Araştırma } \\
\text { Yöntemlerinden } \\
\text { Coklu Yoklama } \\
\text { Modeli }\end{array}$ & $\begin{array}{c}\text { Grafiksel } \\
\text { Analiz }\end{array}$ & $\begin{array}{l}\text { Araştırmanın amacı, zihinsel yetersizliği olan } \\
\text { bireylere serbest zaman becerilerinin küçük } \\
\text { grupla öğretiminde video ipucunun etkililiğini } \\
\text { araştırmaktır. Araştırma sonunda, video ipucuyla } \\
\text { ögretimin serbest zaman becerilerinin küçük } \\
\text { grupla öğretiminde etkili olduğunu ve öğretim } \\
\text { bittikten sonra kazandılan becerileri } \\
\text { korudukların, farkh ortam ve kişilere } \\
\text { genelleyebildiklerini görülmüștür. }\end{array}$ \\
\hline
\end{tabular}

\section{Verilerin Analizi}

Araştırma kapsamında betimsel analiz ile incelenen çalışmalardan elde edilen veriler betimsel istatistikî yöntem (frekans) kullanılarak çözümlenmiştir. Araştırma kapsamında toplanan veriler her bir araştırma sorusuna karşıllk gelecek şekilde verilerin frekansları hesaplanmıştır. Elde edilen veriler tablolar ve grafikler hâlinde sunularak yorumlanmıştır.

\section{Güvenirlik}

Betimsel analiz sürecinde ortaya çıkabilecek herhangi bir yanlılığ önlemek ve güvenirliği belirlemek üzere kodlayıcılar arası güvenirlik analizi yapılmıştır. Güvenirlik analizinde kullanılmak için araştırmadaki temaları içeren kodlama formu hazırlanmıştır. Kodlama formunda, çalışmaların yayınlandığı dergi ya da enstitü, araştırmanın yapıldığı yıl, kullanılan araştırma yöntemi, örneklem grubu, veri analiz yöntemini içeren bölümler yer almıştır. Bu form ile araştırma kapsamına alınan bütün makaleler, araştırmacılar tarafindan bağımsız olarak farklı ortam ve zamanlarda kodlanmıştır. Yapılan kodlamalar arasında tutarlılık incelenerek, değerlendirme yapılmıştır. Buna göre kodlayıc1ların uyuşmayan kodlamalarına geri dönülmüş ve uzlaşma sağlanmıştır. Güvenirlik hesaplamasında, [görüş birliği / (görüş birliği + görüş ayrıllı̆ı) x 100] formülü kullanılmış (Wolery, Bailey ve Sugai, 1988) ve kodlayıcılar arası güvenirlik (uzlaşma sağlandıktan sonra) \%100 olarak bulunmuştur. Güvenirlik belirleme çalışması sona erdikten sonra formlarda yer alan bilgiler araştırmacılar tarafından frekansları tespit edilerek betimsel analiz hâlinde raporlaştırılmıştır.

\section{Bulgular}

Araştırma kapsamında toplanan veriler araştırma soruları temel alınarak analiz edilmiştir. Analizler sonucunda elde edilen bulgular araştırma sorularına paralel olarak izleyen paragraflarda sunulmuştur.

\section{Serbest Zaman Becerileri Araştırmalarının Yer Aldığı Dergiler}

Özel eğitimde serbest zaman becerileri ile ilgili yapılan çalışmaların araştırma türüne göre dağılımları Tablo 2'de verilmiştir. 
Tablo 2. Serbest Zaman Becerileri ile İlgili Yapılan Çalışmaların Araştırma Türüne Göre Dağılımları

\begin{tabular}{lc}
\hline Araştırma Türü & f \\
\hline Yüksek Lisans & 4 \\
Doktora & 2 \\
Makale & 36 \\
\hline Toplam & 42 \\
\hline
\end{tabular}

Tablo 2 incelendiğinde bu çalışmaların 6 tanesinin tez, 36 tanesinin ise makale olduğu görülmektedir. Tez çalışmalarının 4'ünü yüksek lisans, 2'sini ise doktora tezleri oluşturmaktadır. Tezlerin yapıldığı üniversitelere ve enstitülere bakacak olursak şu şekilde sıralanabilir: Anadolu Üniversitesi Eğitim Bilimleri Enstitüsü $(\mathrm{f}=2)$, Abant İzzet Baysal Üniversitesi Eğitim Bilimleri Enstitüsü ( $\mathrm{f}=2$ ), Hacettepe Üniversitesi Sağl1k Bilimleri Enstitüsü (f=1), Gazi Üniversitesi Eğitim Bilimleri Enstitüsü ( $\mathrm{f}=1)$.

Tablo 3. Serbest Zaman Becerileri Araştırmalarının Yer Aldığı Dergiler

\begin{tabular}{ll}
\hline Dergi & f \\
\hline Developmental Medicine \& Child Neurology & 4 \\
International Journal of Disability, Development and Education & 3 \\
Physical \& Occupational Therapy in Pediatrics & 3 \\
Children's Health Care & 2 \\
Clinical Rehabilitation & 2 \\
Abant İzzet Baysal Üniversitesi Eğitim Fakültesi Dergisi & 2 \\
Research in Developmental Disabilities & 2 \\
Ankara Üniversitesi Eğitim Bilimleri Fakültesi Özel Eğitim Dergisi & 1 \\
Niğde Üniversitesi Beden Eğitimi ve Spor Bilimleri Dergisi & 1 \\
Sosyal Bilimler Dergisi & 1 \\
Annals of Leisure Research & 1 \\
Journal of Early Intervention & 1 \\
Disability \& Society & 1 \\
Physical Educator & 1 \\
Child: Care, Health And Development & 1 \\
Behavioral Interventions & 1 \\
Journal of Intellectual Disability Research & 1 \\
CJOT Early Electronic Edition & 1 \\
British Journal of Learning Disabilities & 1 \\
American Journal of Occupational Therapy & 1 \\
International Journal of Special Education & 1 \\
Journal of Visual Impairment \& Blindness & 1 \\
Journal of Applied Research in Intellectual Disabilities & 1 \\
International Journal of Pediatrics & 1 \\
Educational Research and Reviews & 1 \\
\hline
\end{tabular}


Tablo 3 incelendiğinde serbest zaman becerileri ile ilgili 2000-2017 y1ları arasında en çok makalenin Developmental Medicine \& Child Neurology dergisinde yayınlandığı, bunu International Journal of Disability, Development and Education, Physical \& Occupational Therapy in Pediatrics dergilerinin takip ettiği görülmüştür. Araştırma kapsamında incelenen makalelerin 4'ünün Türkiye, 32'sinin ise yurt dış1 adresli dergilerde yayınlanmıştır.

\section{Serbest Zaman Becerileri Araştırmalarının Yıllara Göre Dağılımı}

Şekil 3 incelendiğinde özel eğitimde serbest zaman becerileri ile ilgili yapılan çalışmaların yıllara göre değiştiği görülmektedir. Serbest zaman becerileri ile ilgili yapılan çalışmalar en çok $(\mathrm{f}=8) 2009$ yılında yapılmıştır. 2009 yılını sırasıyla 7 çalışma ile 2006, 5 çalışma ile 2010 ve 4 çalışma ile 2005, 2008 yılları takip etmiştir. Serbest zaman becerileri ile ilgili yapılan çalışmalar en az birer çalışma ile 2000, 2002, 2004, 2011, 2013, 2015 ve 2017 y1llarındadir.

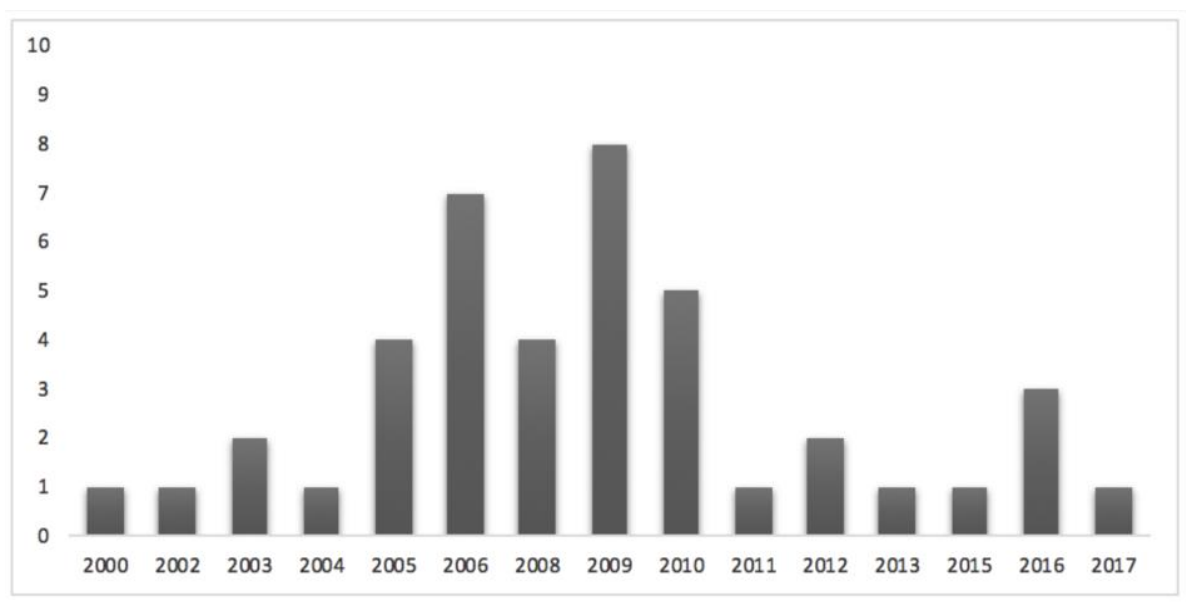

Şekil 3. Serbest zaman becerileri araştırmalarının yıllara göre dağılımı.

\section{Serbest Zaman Becerileri Araştırmalarının Yöntemsel Dağılımı}

Şekil 4'te özel eğitim alanında serbest zaman becerileri ile ilgili yapılan çalışmaların dağılımları görülmektedir. Şekil incelendiğinde serbest zaman becerileri ile yapılan çalışmalarda en çok nicel $(\mathrm{f}=15)$ ve nitel $(\mathrm{f}=15)$ araştırma yöntemlerinin kullanıldığı görülmektedir. Nicel ve nitel araştırma yöntemini tek denekli $(\mathrm{f}=10)$ araştırma yöntemleri takip etmektedir. Nicel araştırma yöntemlerini kullanan araştırmalar genellikle ölçek uygulamışlardır. Kullanılan 
ölçekler incelendiğinde Children's Assessment of Participation and Enjoyment (CAPE) ve Preference for Activity of Children (PAC) ölçeklerinin ça1ışmalarda ağırlıklı olarak kullanıldığı görülmüştür (King ve ark., 2004). Nitel araştırma yöntemlerinin kullanıldığ 1 çalışmalar değerlendirildiğinde katılımcıların günlük tuttukları ve odak grup görüşmelerinin yapıldığı çalışmalar göze çarpmaktadır. Tek denekli araştırma yöntemlerinin kullanıldığı çalışmalarda ise özel gereksinimli bireylere oyun becerileri, seramik eğitimi gibi serbest zaman etkinliklerine katılımlarını artırmaya yönelik etkililik uygulamaları gerçekleştirilmiştir. Tek denekli araştırma yöntemlerinden ise çoklu yoklama, çoklu başlama ve dönüşümlü uygulamalar modelleri en çok kullananlar arasında yer almaktadır. Ayrıca 2 çalışma da hem nicel hem de nitel araştırma yöntemlerinden yararlanılmıştır.

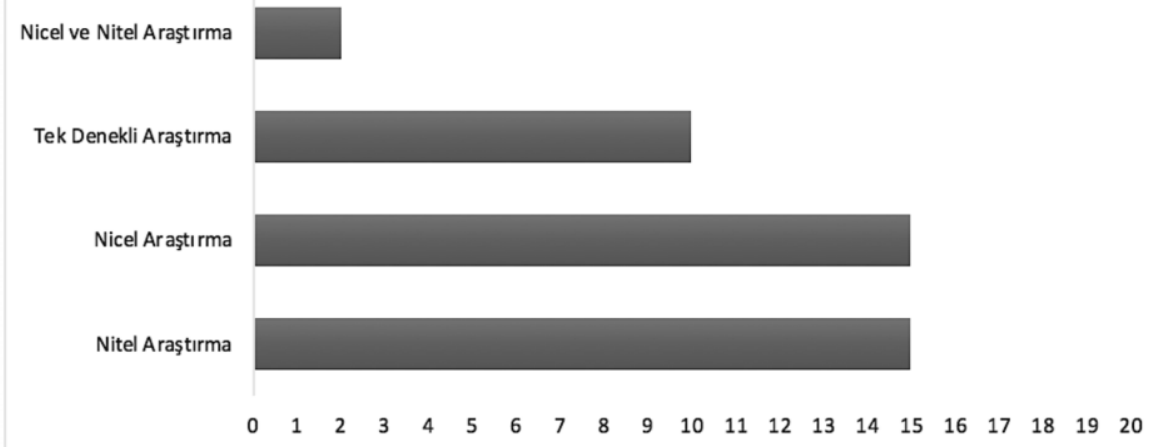

Şekil 4. Serbest zaman becerileri araştırmalarının yöntemsel dağılımı

\section{Serbest Zaman Becerileri Araştırmalarının Örneklem Dağılımı}

Özel Eğitim alanında serbest zaman becerileri ile ilgili yapılan çalışmaları örneklem özellikleri bakımından iki farklı açıdan incelenmiştir. 42 çalışmanın 38'i örneklem olarak özel gereksinimli bireyler, normal gelişim gösteren bireyler ve ailelerini seçmiş; 4 çalışma ise alanyazından yola çıkarak çalışmalarına örneklem belirlemişlerdir.

Örneklemi bireylerden oluşan çalışmaların örneklem sayılarının dağılımı Tablo 4’te görüldüğü gibidir. 
Tablo 4. Seçilen Örneklem Sayılarının Dağılımı

\begin{tabular}{lc}
\hline Örneklem sayılarının dağılım sıkıkları & f \\
\hline $1-10$ arası & 13 \\
$11-20$ aras 1 & 2 \\
$21-30$ aras 1 & 5 \\
$31-40$ aras 1 & 0 \\
$41-50$ aras 1 & 0 \\
51 ve daha fazla & 18 \\
\hline Toplam & 38 \\
\hline
\end{tabular}

Tablo 4'te görüldüğü üzere özel eğitim alanında serbest zaman becerileri ile ilgili yapılan çalışmaların en çok $(\mathrm{f}=18) 51$ ve daha fazla örneklem seçme yoluna gitmişlerdir. Bunu 1-10 arasında örneklem sayısı seçen çalışmalar ( $\mathrm{f}=13)$ takip etmektedir.

Tablo 5'te çalışmalarda yer verilen örneklem düzeyleri görülmektedir. Özel Eğitim alanında serbest zaman becerileri ile ilgili bireyler ile yapılan çalışmalar katılımcı özelliklerine göre incelendiğinde çalışmalarda en fazla ( $\mathrm{f}=23$ ) yalnızca özel gereksinimli öğrencileri örneklem düzeyi olarak seçilmektedir. Bunu özel gereksinimli öğrenciler ve ailelerini örneklem alan çalışmalar ( $\mathrm{f}=8$ ) takip etmektedir. Ayrıca özel gereksinimli ve normal gelişim gösteren bireylerin birlikte yer aldığı çalışmalar $(\mathrm{f}=4)$ vardır. Bununla birlikte yalnızca aileleri örneklem alan çalışmalara $(\mathrm{f}=3)$ da rastlanmıştır.

Tablo 5. Örneklem Düzeylerinin Seçilme Sıklıkları

\begin{tabular}{lc}
\hline Örneklem Düzeyi & f \\
\hline Özel Gereksinimli Bireyler & 23 \\
Özel Gereksinimli Bireyler ve Aileleri & 8 \\
Özel Gereksinimli Bireyler ve Normal Gelişim Gösteren Bireyler & 4 \\
Aileler & 3 \\
\hline Toplam & 38 \\
\hline
\end{tabular}

Tablo 5'te serbest zaman becerileri ile ilgili yapılan çalışmaların örneklem düzeylerini ağırlıklı olarak özel gereksinimli bireylerin oluşturduğu görülmektedir. Özel gereksinimli bireylerin tanı özelliklerinin verildiği çalışmalar incelendiğinde çalışmalarda sırasıyla en çok zihinsel yetersizlik, otizm spektrum bozukluğu, fiziksel yetersizlik gösteren bireylerden oluşan örneklemlerin seçildiği görülmektedir. Bu grupları Serebral Palsi olan bireyleri örneklem seçen çalışmalar takip etmektedir. Bununla birlikte az da olsa görme, ağır düzeyde yetersizlik ve çoklu yetersizlik gösteren bireyleri örneklem seçen 
çalışmalara da rastlanılmıştır.

\section{Serbest Zaman Becerileri Araştırmalarının Veri Analiz Yöntemlerine Göre Dağılımı}

Tablo 6, özel eğitim alanında serbest zaman becerileri ile ilgili yapılan çalışmalarda yaygın olarak kullanılan veri analiz yöntemlerini yansıtmaktadır.

Tablo 6. Veri Analiz Yöntemlerinin Dağılımları

\begin{tabular}{lcccc}
\hline & \multicolumn{4}{c}{ Araştırma Yöntemleri } \\
\hline Analiz Yöntemleri & $\begin{array}{c}\text { Nicel } \\
\text { Arş. }\end{array}$ & $\begin{array}{c}\text { Nitel } \\
\text { Arş. }\end{array}$ & $\begin{array}{c}\text { Tek } \\
\text { Denekli Arş. }\end{array}$ & $\begin{array}{c}\text { Nicel ve } \\
\text { Nitel Arş. }\end{array}$ \\
\hline İstatistiksel Analiz & 13 & 5 & & 2 \\
Grafiksel Analiz & 1 & & 10 & \\
İçerik Analizi & & 3 & & \\
Betimsel Analiz & & 3 & & \\
Betimsel ve İçerik Analizi & & 2 & & \\
Betimsel ve Yorumlayıc1 Analiz & & 1 & \\
Tümevarımsal Analiz & & 1 & & \\
İstatistiksel Analiz ve Betimsel Analiz & 1 & & & \\
\hline
\end{tabular}

Tablo 6 incelendiğinde nicel araştırma yöntemlerinin kullanıldığı çalışmalarda çoğunlukla istatistiksel analiz yöntemlerine müracaat edildiği görülmektedir. Bu istatistiksel analiz sürecinde bazı programlardan yararlanılmıştır. Bu programlardan en yaygın olarak kullanılanı SPSS paket programıdır. SPSS'e ek olarak SAS, Mplus ve SUDAAN programları da istatistiksel analiz için çalışmalarda tercih edilmiştir. Nitel araştırma yöntemlerinin kullanıldığ çalışmalarda sıklıkla istatistiksel yöntemler kullanılmıştır. İstatistiksel yöntemleri içerik ve betimsel analiz türleri takip etmiştir. Ayrıca betimsel ve içerik analizinin birlikte kullanıldığı çalışmalara da ulaşı1mıştır. Tek denekli araştırma yöntemlerinin kullanıldığı çalışmalara baktığımız zaman bu çalışmaların hepsinin grafiksel analiz sürecini kullandıkları ve verilerini buna göre yorumladıkları görülmektedir. Son olarak nicel ve nitel araştırma yöntemlerinin birlikte kullanıldığı çalışmalarda analiz sürecinde istatistiksel analiz yöntemlerinin kullanılmıştır.

\section{Sonuç ve Tartışma}

Bu araştırmada, Türkiye ve yurt dışı adresli özel eğitimde serbest zaman becerileri ile ilgili 2000-2017 yılları arasında yapılmış olan çalışmaları; araştırma türü, yayımlandığı yer, yılı, araştırma yöntemleri, örneklem düzeyleri, örneklem sayıları ve veri analiz yöntemleri açısından incelenmiştir. 
Araştırmada, 2000-2017 yılları arasında en çok makalenin Developmental Medicine \& Child Neurology dergisinde yayınlandığı, bunu International Journal of Disability, Development and Education, Physical \& Occupational Therapy in Pediatrics dergilerinin takip ettiği belirlenmiştir. İncelenen makalelerin 4'ünün Türkiye adresli dergilerde, 32'sinin ise yabancı dergilerde yayınlandığı görülmüştür. Bu durum Türkiye'deki ve diğer araştırmacıların çalışmalarını daha geniş bir okuyucuya sunma isteğinden kaynaklanabileceği söylenebilir. Ayrıca araştırmaların yıllara göre dağılımları incelendiğinde serbest zaman becerileri ile ilgili en çok 2009 yılında çalışma yapıldığ 1 görülmüştür. 2009 y1lını sırasıyla 7 çalışma ile 2006, 5 çalışma ile 2010 ve 4 ça1ışma ile 2005 yılları takip etmiştir. Çalışmaların 2005-2010 yılları arasında artış ve 2010 yılından sonra serbest zaman becerileri ile ilgili yapılan çalışmaların genel olarak azaldığı belirlenmiştir. 2005-2010 yılları arasında araştırmacıların rağbet gösterdiği bir çalışma alanı olan serbest zaman becerilerinin 2010 yılından sonra azalış göstermesinin nedeninin özel eğitimde farklı alanların ön plana çıkması ve araştırmacıların bu alanlara kaymış olabileceği düşünülebilir.

Bulgularda özel eğitim alanında serbest zaman becerileri ile ilgili yap1lan çalışmalarda nicel ve nitel yöntemlerin ön planda olduğu görülmüştür. Nicel ve nitel yöntemleri tek denekli araştırma yöntemleri izlemiştir. Çalışmalarda nitel ve nicel yöntemlerin sıklıkla kullanılmasının nedenleri olarak nitel yaklaşımın daha esnek bir yapıya sahip olması ve genelleme amacının ön planda olmaması ve nicel yaklaşımların geniş örneklemlere ulaşma, zaman ve maliyet bakımından avantaj sağlaması gösterilebilir. Ayrıca çalışmalarda nicel yöntemlerde ölçeklerden nitel araştırma yöntemlerde günlüklerin ve görüşmelerden veri toplama aracı olarak sıklıkla yararlanıldığg belirlenmiş̧ir.

Örneklem sayıları incelendiğinde çalışmaların 51 ve üstü aralığında gerçekleştirildiği ortaya çıkmıştır. Araştırma yöntemlerine göre örneklem sayıları incelendiğinde ise nitel araştırma yönteminin ağırlıklı kullanılmasına rağmen örneklem sayısının böyle olmasının nedeni nitel çalışmalar ile eşit sayıda çalışılan nicel araştırmaların örneklem sayılarının fazla olmasındandır. Bu sayıyı tek denekli araştırma yöntemlerinin kullanıldığı çalışmalardan kaynaklı olarak 1-10 aralığında örneklem sayısı takip etmektedir. Serbest zaman becerileri ile ilgili yapılan çalışmalardan alan yazın derleme çalışmaları çıkarıldıktan sonra örneklem düzeylerini ağırlıklı olarak özel gereksinimli birey- 
lerin oluşturduğu görülmektedir. Özel gereksinimli bireylerin tanı özelliklerini incelediğimizde en çok zihinsel yetersizlik, otizm spektrum bozukluğu, fiziksel yetersizlik gösteren bireylerden oluşan örneklemlerin seçildiği görülmektedir.

Araştırmada nicel çalışmalarda yaygın olarak istatistiksel analiz yöntemlerinden, nitel çalışmalarda istatistiksel, içerik, betimsel analiz yöntemlerinden, tek denekli çalışmalarda grafiksel analiz yöntemlerinden yararlanıldığı belirlenmiştir.

Özet olarak araştırmanın Türkiye ve yurt dışında özel eğitim alanında serbest zaman becerileri ile ilgili çalışmalarının eğilimlerini belirlemeye incelenen çalışma sayısı ve araştırma soruları açısından kapsamlı olduğu belirtilebilir. Araştırmada elde edilen sonuçların alanda gerçekleştirilen çalışmaların güçlü ve eksik yönlerinin görülmesinde yararlı olacağı ve gelecek çalışmalara yön vermede belirleyici bir kaynak olabileceği söylenebilir. Buna karşın araştırma sonuçlarının 2000-2017 yılları arasında tam metnine ulaşılabilen çalışmalarla sinırlıdır.

\section{Kaynakça}

Aitchison, C. (2000). Young disabled people, leisure and everyday life: Reviewing conventional definitions for leisure studies. Annals of Leisure Research, 3(1), 1-20.

Aitchison, C. (2003). From leisure and disability to disability leisure: Developing data, definitions and discourses. Disability \& Society, 18(7), 955969.

Doi: $10.1080 / 0968759032000127353$

Altundağ, M., Ural, M., Eratay, E. ve Aydoğan, Y. (2017). Yetersizliği olan ve olmayan okulöncesi çocuklara verilen seramik eğitimi ve uygulamaların değerlendirilmesi. Abant İzzet Baysal Üniversitesi Eğitim Fakültesi Dergisi, 17(1), 1-16.

Aslan, Y. ve Eratay, E. (2009). Zihin engelli bireylere kumaş üzerine çizilen desene pul işleme becerisinin öğretiminde eşzamanlı ipucuyla öğretimin etkililiği. Ankara Üniversitesi Ĕgitim Bilimleri Fakültesi Özel Eğitim Dergisi, 10(2), 15-34.

Baş, T. ve Akturan, U. (2013). Nitel araştırma yöntemleri. Ankara: Seçkin. 
290 Arş. Gör. Nesime Kübra TERZİoĞLU / Dr. Öğr. Üyesi Müzeyyen ELDENİZ-ÇETÍN

Bayram, E. (2016). Zihinsel yetersizliği olan ve olmayan ergenlerin boş zamanlarını değerlendirme biçimleri. Yayınlanmamış yüksek lisans tezi, Abant İzzet Baysal Üniversitesi Eğitim Bilimleri Enstitüsü.

Braun, K. V. N., Yeargin-Allsopp, M. ve Lollar, D. (2006). Factors associated with leisure activity among young adults with developmental disabilities. Research in Developmental Disabilities, 27(5), 567-583.

Brown, M. ve Gordon, W. A. (1987). Impact of impairment on activity patterns of children. Archives of Physical Medicine and Rehabilitation, $68,828-832$.

Brown, R. I., Brown P. M. ve Bayer, M. B. (1994). A quality of life model: New challenges arising from a six year study. D. Goode, (Ed.), Quality of life for persons with disabilities içinde (39-56). Cambridge, MA: Brookline.

Bult, M. K., Verschuren, O., Gorter, J. W., Jongmans, M. J., Piškur, B. ve Ketelaar, M. (2010). Cross-cultural validation and psychometric evaluation of the Dutch language version of the Children's Assessment of Participation and Enjoyment (CAPE) in children with and without physical disabilities. Clinical Rehabilitation, 24(9), 843-853.

Bult, M. K., Verschuren, O., Jongmans, M. J., Lindeman, E. ve Ketelaar, M. (2011). What influences participation in leisure activities of children and youth with physical disabilities? A systematic review. Research In Developmental Disabilities, 32(5), 1521-1529.

Caldwell, L. L. ve Gilbert, A. A. (1990). Leisure, health, and disability: A review and discussion. Canadian Journal of Community Mental Health, 9(2), 111-122.

Çankaya, Ö. ve Eratay, E. (2012). Zihinsel engelli öğrencilere harosa örgü örme becerisinin öğretiminde eş zamanlı ipucuyla öğretimin etkililiği. Abant İzzet Baysal Üniversitesi Eğitim Fakültesi Dergisi, 11(2), 1134.

Çay, E. (2017). Zihinsel yetersizliği olan bireylere serbest zaman becerilerinin küçük grupla ögrretiminde video ipucunun etkililiği. Yayınlanmamış yüksek lisans tezi, Abant İzzet Baysal Üniversitesi Eğitim Bilimleri Enstitüsü. 
Çöl, G. (2015). Özel gereksinimi olan çocukların boş zaman aktivitelerine katılımını etkileyen faktörler. Yayınlanmamış yüksek lisans tezi, Hacettepe Üniversitesi Sağlık Bilimleri Enstitüsü.

Çuhadar, S. (2008). Resimli etkinlik çizelgeleri ile sunulan ögrretim sürecinin otistik özellikler gösteren çocukların serbest zaman becerilerini öğrenmeleri üzerindeki etkililiği. Yayınlanmamış doktora tezi, Anadolu Üniversitesi Eğitim Bilimleri Enstitüsü.

Diken, İ. (Ed.). (2012). Özel eğitime gereksinimi olan ögrenciler ve özel ĕgitim. (6. bask1). Ankara: Pegem Akademi.

Eldeniz-Çetin. M. ve Çay, E. (2016). Zihinsel yetersizliği olan öğrencilere bowling becerisinin öğretiminde eşzamanli ipucuyla öğreimin etkililiği. Sosyal Bilimler Dergisi, 3(9), 441-455.

Eratay, E. (2013). Effectiveness of leisure time activities program on social skills and behavioral problems in individuals with intellectual disabilities. Educational Research and Reviews, 8(16), 1437.

Eripek, S. (2003). Zeka geriligi olan çocuklar. A. Ataman, (Ed.). Özel gereksinimli çocuklar ve özel egitime giriş içinde (153-173). Ankara: Gündüz Eğitim ve Yayıncılık.

Fidler, G. S. ve Fidler, J. W. (1978). Doing and becoming: Purposeful action and self-actualization. American Journal of Occupational Therapy, 32, 305-310.

Fischer, M. ve Barkley, R. (2006). Young adult outcomes of children with hyperactivity: Leisure, financial, and social activities. International Journal of Disability, Development and Education, 53(2), 229-245.

Hayden, M. F., Lakin, K. C., Hill, B. K. ve Bruininks, R. H. (1992). Social and leisure integration of people with mental retardation in foster homes and small group homes. Education and Training in Mental Retardation, 27, 187-99.

Heah, T., Case, T., McGuire, B. ve Law, M. (2007). Successful participation: The lived experience among children with disabilities. Canadian Journal of Occupational Therapy, 74(1), 38-47.

Hilton, C. L., Crouch, M. C. ve Israel, H. (2008). Out-of-school participation patterns in children with high-functioning autism spectrum disorders. 
American Journal of Occupational Therapy, 62(5), 554-563.

Imms, C. (2008). Review of the children's assessment of participation and enjoyment and the preferences for activity of children. Physical \& Occupational Therapy In Pediatrics, 28(4), 389-404.

Ittenbach, R. F., Bruininks, R. H., Thurlow, M. L. ve McGrew, K. S. (1993). Community integration of young adults with mental retardation: A multivariate analysis of adjustment. Research in Developmental Disabilities, 14(4), 275-290.

İlhan, L. (2009). Zihinsel engelli çocuğu olan anne-babaların çocuklarının özel eğitimleri sürecinde beden eğitimi ve spor etkinliklerine yaklaşımlarının değerlendirilmesi. Beden Egitimi ve Spor Bilimleri Dergisi, $3(1), 38-48$.

Jessup, G. M., Cornell, E. ve Bundy, A. C. (2010). The treasure in leisure activities: Fostering resilience in young people who are blind. Journal of Visual Impairment \& Blindness, 104(7), 419-430.

King, G., Law, M., King, S., Rosenbaum, P., Kertoy, M. K. ve Young, N. L. (2003). A conceptual model of the factors affecting the recreation and leisure participation of children with disabilities. Physical \& Occupational Therapy in Pediatrics, 23, 63-90.

King, G. A., Law, M., King, S., Hurley, P., Rosenbaum, P., Hanna, S., Kertoy, M., Rosenbaum, P. ve Young, N. (2004). Children's assessment of participation and enjoyment and preferences for activities of kids. San Antonio, TX: PsychCorp.

King, G., Law, M., Hanna, S., King, S., Hurley, P., Rosenbaum, P., Kertoy, M. ve Petrenchik, T. (2006). Predictors of the leisure and recreation participation of children with physical disabilities: A structural equation modeling analysis. Children's Health Care, 35(3), 209-234.

King, G., McDougall, J., DeWit, D., Petrenchik, T., Hurley, P. ve Law, M. (2009). Predictors of change over time in the activity participation of children and youth with physical disabilities. Children's Health Care, 38(4), 321-351.

King, G., Petrenchik, T., Law, M. ve Hurley, P. (2009). The enjoyment of formal and informal recreation and leisure activities: A comparison of 
school-aged children with and without physical disabilities. International Journal of Disability, Development and Education, 56(2), 109130.

King, G., Law, M., Hurley, P., Petrenchik, T. ve Schwellnus, H. (2010). A developmental comparison of the out-of-school recreation and leisure activity participation of boys and girls with and without physical disabilities. International Journal of Disability, Development and Education, 57(1), 77-107.

Kinney, V. B. ve Coyle, C. P. (1992). Predicting life satisfaction among adults with physical disabilities. Archives of Physical Medicine and Rehabilitation, 73, 863-869.

Köse, E. (2006). Özel eğitim gereksinimi olan çocukların gelişimine seramik eğitiminin etkisi. Yayınlanmamış yüksek lisans tezi, Gazi Üniversitesi Eğitim Bilimleri Enstitüsü.

Kurt, O. (2006). Otistik özellikler gösteren çocuklara zincirleme serbest zaman becerilerinin ögrretiminde sabit bekleme süreli öğretimin ve eşzamanlı ipucuyla öğretimin gömülü öğretimle sunulmasının etkililik ve verimliliklerinin karşılaşstırlması. Yayınlanmamış doktora tezi, Anadolu Üniversitesi Eğitim Bilimleri Enstitüsü.

Law, M., King, G., King, S., Kertoy, M., Hurley, P., Rosenbaum, P., Young, N. ve Hanna, S. (2006). Patterns of participation in recreational and leisure activities among children with complex physical disabilities. Developmental Medicine \& Child Neurology, 48(5), 337-342.

Lyons, R. F. (1993). Meaningful activity and disability: Capitalizing upon the potential of outreach recreation networks in Canada. Canadian Journal of Rehabilitation, 6(4), 256-265.

MacDonald, R., Clark, M., Garrigan, E. ve Vangala, M. (2005). Using video modeling to teach pretend play to children with autism. Behavioral Interventions, 20(4), 225-238.

Majnemer, A., Shevell, M., Law, M., Birnbaum, R., Chilingaryan, G., Rosenbaum, P. ve Poulin, C. (2008). Participation and enjoyment of leisure activities in school-aged children with cerebral palsy. Developmental Medicine \& Child Neurology, 50(10), 751-758. 
Majnemer, A. (2009). Promoting participation in leisure activities: Expanding role for pediatric therapists. Physical \& Occupational Therapy in Pediatrics, 29, 1-5.

McManus, V., Corcoran, P. ve Perry, I. J. (2008). Participation in everyday activities and quality of life in pre-teenage children living with cerebral palsy in South west Ireland. BMC Pediatrics, 8(1), 50-60.

Milli Eğitim Bakanlığı. (2006). Milli Eğitim Bakanlı̆̆ı özel eğitim hizmetleri yönetmeliği.

https://orgm.meb.gov.tr/meb_iys_dosya-

lar/2012_10/10111226_ozel_egitim_hizmetleri_yonetmeligi_son.pdf

Morrison, R. S., Sainato, D. M., Benchaaban, D. ve Endo, S. (2002). Increasing play skills of childen with autism using activity schedules and correspondence training. Journal of Early Intervention, 25(1), 58-72.

Orlin, M. N., Palisano, R. J., Chiarello, L. A., Kang, L. J., Polansky, M., Almasri, N. ve Maggs, J. (2010). Participation in home, extracurricular, and community activities among children and young people with cerebral palsy. Developmental Medicine \& Child Neurology, 52(2), 160166.

Parmenter, T. R., Cummins, R., Shaddock, A. J. ve Stancliffe, R. (1994). The view from Australia: Australian legislation, service delivery, and quality of life. D. Goode, (Ed.), Quality of life for persons with disabilities içinde (75-102). Cambridge, MA: Brookline.

Schleien, S., Green, F. ve Heyne, L. (1993). Integrated community recreation. M. Snell, (Ed.), Instruction of students with severe disabilities içinde (526-555). New York: MacMillan.

Shikako-Thomas, K., Dahan-Oliel, N., Shevell, M., Law, M., Birnbaum, R., Rosenbaum, P., Poulin, C. ve Majnemer, A. (2012). Play and be happy? Leisure participation and quality of life in school-aged children with cerebral palsy. International Journal of Pediatrics.

Doi: $10.1155 / 2012 / 387280$

Simpkins, S. D., Ripke, M., Huston, A. C. ve Eccles, J. S. (2005). Predicting participation and outcomes in out-of-school activities: Similarities and differences across social ecologies. New Directions for Youth Development, 105, 51-69. 
Solish, A., Perry, A. ve Minnes, P. (2010). Participation of children with and without disabilities in social, recreational and leisure activities. Journal of Applied Research in Intellectual Disabilities, 23(3), 226-236.

Voorman, J. M., Dallmeijer, A. J., Schuengel, C., Knol, D. L., Lankhorst, G. J. ve Becher, J. G. (2006). Activities and participation of 9-to 13-yearold children with cerebral palsy. Clinical Rehabilitation, 20(11), 937948.

Vuran, S. (2008). Empowering leisure skills in adults with autism: An experimental investigation through the most to least prompting procedure. International Journal of Special Education, 23(1), 174-181.

Wolery, M. R., Bailey, D. B. ve Sugai, G. M. (1988). Effective teaching: Principles and procedures of applied behavior analysis with exceptional students. Boston: Allyn \& Bacon.

Yalon-Chamovitz, S., Mano, T., Jarus, T. ve Weinblatt, N. (2006). Leisure activities during school break among children with learning disabilities: Preference vs. performance. British Journal of Learning Disabilities, 34, 42-48.

Yıldırım, A., ve Şimşek, H. (2016). Sosyal bilimlerde nitel araştırma yöntemleri. Ankara: Seçkin.

Zhang, J., Cote, B., Cihen, S. ve Liu, J. (2004). The effect of a constant time delay procedure on teaching an adult with severe mental retardation a recreation bowling skills. Physical Educator, 61(2), 63-74.

Zijlstra, H. P. ve Vlaskamp, C. (2005). Leisure provision for persons with profound intellectual and multiple disabilities: Quality time or killing time? Journal of Intellectual Disability Research, 49(6), 434-448. 